AGRITECH, Vol. 37, No. 3, Agustus 2017, Hal. 288-294 DOI: http://doi.org/10.22146/agritech.10639 ISSN 0216-0455 (Print), ISSN 2527-3825 (Online) Tersedia online di https://jurnal.ugm.ac.id/agritech/

\title{
Fungal Population of Nutmeg (Myristica fragrans) Kernels Affected by Water Activity during Storage
}

\author{
Kiki Nurtjahja ${ }^{1,2}$, Okky Setyawati Dharmaputra, ${ }^{1,3 *}$, Winiati Puji Rahayu ${ }^{4,5}$, Rizal Syarief Syaiful Nazli4,5 \\ ${ }^{1}$ Department of Biology, Faculty of Mathematics and Natural Sciences, Bogor Agricultural University, \\ Jalan Agatis, Campus IPB Dramaga Bogor 16680, Indonesia \\ ${ }^{2}$ Department of Biology, Faculty of Mathematics and Natural Sciences Sumatera Utara University, \\ Jalan Bioteknologi no. 1 Campus USU, Medan 20155, Indonesia \\ ${ }^{3}$ SEAMEO BIOTROP, Jalan Raya Tajur km 6, Bogor 16134, Indonesia \\ ${ }^{4}$ Department of Food Science and Technology, Faculty of Agricultural Technology, Bogor Agricultural University, \\ Campus IPB Dramaga, PO Box 220 Bogor 16680, Indonesia \\ ${ }^{5}$ SEAFAST Center, Bogor Agricultural University, Jalan Ulin no. 1 Campus IPB, Dramaga, Bogor 16680, Indonesia \\ Email: okky@biotrop.org
}

Submission: 18 April 2016; Accepted: 10 Februari 2017

\begin{abstract}
The aim of this investigation was to determine the effect of various water activities $\left(\mathrm{a}_{\mathrm{w}}\right)$ on fungal population in nutmeg kernels during storage. The seed nutmegs were obtained from ripe fruits one week after they fell on the ground in North Minahasa Regency, North Sulawesi Province, Indonesia. The kernels (moisture content $\pm 10 \%$ ) were stored 0 , 15 , and 30 days in various $\mathrm{a}_{\mathrm{w}}(0.75,0.80,0.83,0.90,0.97)$ using saturated salt solutions at $29^{\circ} \mathrm{C}$ in sorption containers. Serial dilution method followed by a pour-plate method in Dichloran 18\% Glycerol Agar (DG18) was used to isolate and quantify the fungal population. Results revealed that kernels stored at $\mathrm{a}_{\mathrm{w}}=0.75$ was not significantly $(p<0.05)$ different from at $\mathrm{a}_{\mathrm{w}}=0.80-0.83$. Fungal population of kernels determined $\mathrm{a}_{\mathrm{w}}$ and significantly $(p<0.05)$ influenced by duration of storage. Range of $\mathrm{a}_{\mathrm{w}} 0.80-0.83$ has a smaller total fungal population than $\mathrm{a}_{\mathrm{w}} \geq 0.90$. Thirteen different genera/species were isolated and identified including Aspergillus and Eurotium (6 species), Penicillium (3 species), Fusarium (2 species), 1 species each of Cladosporium or Syncephalastrum, and isolate A. The largest total fungal population $\left(5.0 \times 10^{5} \mathrm{CFU} \mathrm{g}^{-1}\right)$ was present at the beginning of storage $\left(\mathrm{a}_{\mathrm{w}}=0.97\right)$ and it was dominated by Penicillium citrinum $\left(2.6 \times 10^{5} \mathrm{CFU} \mathrm{g}^{-1}\right)$ followed by Cladosporium cladosporioides $\left(1.7 \times 10^{5} \mathrm{CFU} \mathrm{g}^{-1}\right)$. After 30 days of storage $\left(\mathrm{a}_{\mathrm{w}}=0.97\right)$ the population of $P$. citrinum was still dominant with a population of $2.4 \times 10^{4} \mathrm{CFU} \mathrm{g}^{-1}$. Eurotium chevalieri followed with a population of $1.2 \times 10^{4} \mathrm{CFU} \mathrm{g}^{-1}$.
\end{abstract}

Keywords: Fungal population; moisture content; nutmeg; water activity

\section{INTRODUCTION}

Nutmeg (Myristica fragrans Houtt.) is one of the most important export commodities. Approximately 75\% (8,943 tones) of the world's nutmeg originates from Indonesia (Codex Alimentarius Commission, 2014). A large number of aromatic compounds render Indonesian nutmeg strong in taste with a distinctive aroma. In addition, the production practices of nutmeg are organic and do not rely on the use of chemical fertilizer or pesticides (Codex Alimentarius Commission, 2014). Based on the statistical data of the Directorate General of Estate Crops (2013), 133,732 hectares were in planted with nutmeg in 2012 in Indonesia to yield a production of 25,233 tons. The distribution area covered 19 provinces. The largest total area cultivated with nutmeg was located in North Moluccas (33\%), followed by Nanggroe Aceh Darussalam (23\%), North Sulawesi (18\%), Moluccas (12\%), West Java $(5 \%)$, and the remaining provinces $(9 \%)$. 
Nutmeg mainly produced by small-scale farmers where harvest and warehouse storage condition often damage quality of the kernels. Nutmeg is harvested by collecting the seeds from the ground, drying them in open air on the ground and storing them in warm, humid conditions. During the drying process, the temperature and relative humidity $(\mathrm{RH})$ are beyond control of the majority of farmers. As a result, stored nutmegs are susceptible to infection by fungi (Martins et al., 2001; Dharmaputra et al., 2015).

Soil is the source for contamination of diverse strains of fungi on spices in the fields (Kneifel et al., 1994). Postharvest practices such as drying, transportation and storage increase additional contamination (Hussain et al., 2012). Dried-stored nutmeg like other stored products are hygroscopic and tend to absorb water vapor from the environment. This process leads to an increase in kernel moisture content that results in accelerated deterioration. The deterioration of most spices is caused by filamentous fungus that survive during drying and storage (Stankovic et al., 2006; Toma and Abdulla, 2013). The hard shell of the nuts is a good barrier against fungal infection (Campbell et al., 2013), however, the degree of fungal infection depends on environment, moisture content, temperature, matrix composition, and physical damage (Chiou et al., 1984; Varga et al., 2009; Škrinjar et al., 2012,). Only a few studies concerning fungal infection related to water activity on nutmeg. To inhibit fungal development during storage, the moisture content of the surrounding air should be lowered (Jayas and White, 2003). The objective of this study was to investigate the effect water activities on fungal population on nutmeg kernels during storage.

\section{MATERIALS AND METHODS}

\section{Collecting Nutmeg Seeds, Shelling, and Drying}

We obtained nutmeg kernels from ripe fruits within one week falling on the ground (i.e., the fruits naturally matured). We collected the fruits from plants cultivated in Kauditan sub-district, North Minahasa Regency, North Sulawesi Province, Indonesia in June 2015. The seeds were dried for 7 days by sun-drying and smoke-drying until their moisture content reach $\pm 10 \%$. The seeds were shelled using a wooden hammer. Only intact kernels were used in this experiment.

\section{Preparation of Saturated Salt Solutions}

Five water activities $\left(\mathrm{a}_{\mathrm{w}}\right)$ were controlled, i.e., 0.75, $0.80,0.83,0.90$ and 0.97 by saturated salt solutions i.e. $\mathrm{NaCl},\left(\mathrm{NH}_{4}\right)_{2} \mathrm{SO}_{4}, \mathrm{KCl}, \mathrm{BaCl}_{2}$ and $\mathrm{K}_{2} \mathrm{SO}_{4}$ respectively. The preparation of each salt solution followed the procedure of Kitic et al. (1986). As much as $200 \mathrm{~g}$ of salt was placed in a 51 sorption container containing 2001 of distilled water. The solution was mixed homogenously until saturated and selected water activity $\left(\mathrm{a}_{\mathrm{w}}\right)$ was obtained. We used distilled water $\left(\mathrm{a}_{\mathrm{w}=} 0.99\right)$ as a control. During storage the salt solutions were saturated at $29^{\circ} \mathrm{C}$. Based on thermo-hygrograph data obtained at every sampling, the $\mathrm{a}_{\mathrm{w}}$ and temperature inside each sorption container remained constant throughout the entire duration of the experiment.

\section{Packaging and Storage of Nutmeg Kernels}

As much as $200 \mathrm{~g}$ of nutmeg kernels (moisture content $\pm 10 \%$ ) were placed in a plastic netting sack. The sack was then hung in sorption containers (3 sacks per container). The kernels were stored in sorption containers with different $\mathrm{a}_{\mathrm{w}}$. The duration of storage was 0,15 , and 30 days. Three replicates $\left(i, e .,=3\right.$ sorption containers) were used for each $\mathrm{a}_{\mathrm{w}}$ and storage duration. The sorption containers were placed on a wooden table at room temperature $\left( \pm 28^{\circ} \mathrm{C}\right)$.

\section{Sampling Method for Obtaining a Working Sample}

We collected samples of nutmeg kernels from each sack. The kernels from each sack in the three sorption containers were collected for each storage duration. Each sample was then ground for 30 seconds (25 $000 \mathrm{rpm}$ ) using a Mill Powder RT-04 no. Serie 980923 (Mill Powder Tech. Co LTD, Taiwan), mixed homogenously and manually divided into 3 parts to obtain working samples to determine moisture content, fungal population and reserved samples.

\section{Determination of Kernel Moisture Content and Fungal Population}

Moisture content of the kernels was determined based on wet basis using a distillation method according to Standard Nasional Indonesia (SNI) (1993). All fungal species from each sample were isolated and quantified using a serial dilution method, followed by the pour-plate method on Dichloran 18\% Glycerol Agar (DG18) (10 g/L glucose, 5 $\mathrm{g} / \mathrm{L}$ peptone, $1 \mathrm{~g} / \mathrm{L} \mathrm{KH}_{2} \mathrm{PO}_{4}, 0.5 \mathrm{~g} / \mathrm{L} \mathrm{MgSO}_{4} .7 \mathrm{H}_{2} \mathrm{O}, 220 \mathrm{~g} / \mathrm{L}$ glycerol, $15 \mathrm{~g} / \mathrm{L}$ bacto agar, $2.0 \mathrm{mg} / \mathrm{L}$ dichloran and $100 \mathrm{mg} / \mathrm{L}$ chloramphenicol (Pitt and Hocking, 2009). The plates were incubated for 7 days at room temperature $\left( \pm 28^{\circ} \mathrm{C}\right)$. Fungal species was determined based on the procedure of Pitt and Hocking (2009).

\section{Statistical Analysis}

We employed a completely randomized design factorial. The factors were water activities and storage duration. We analyzed the observed data using analysis of variance (ANOVA) for statistically significant differences, followed by Duncan's multiple range test at the $5 \%$ probability level. We used the Statistical Analysis System (SAS) software (version 9.13 ) statistical package (SAS Institute Inc. North Carolina). 


\section{RESULTS AND DISCUSSION}

\section{Equilibrium Kernels Moisture Content}

In order to prevent fungal deterioration during storage, the highest moisture content of nutmeg kernel should be $10 \%$ (Standard Nasional Indonesia, 1993). However, environmental factors particularly $\mathrm{a}_{\mathrm{w}}$ affect the physical properties of the kernels. In storage, dry kernels are hygroscopic and tend to absorb or release water from and into surrounding air, this process continues until the kernels reach equilibrium with the moisture in the atmosphere (Daniel et al., 2012; Jyoti and Malik, 2013). Moisture equilibrium of the kernels in the sorption containers was indicated by their attaining a constant weight after a certain storage duration. This equilibrium was attained after different amounts of time depending on $a_{w}$ (saturated salts solutions used). The shortest moisture equilibrium of the kernels occurred at $a_{w}$ $=0.75$ after 10 days of storage; no significant differences ( $p$ $<0.05)$ in kernels weight were observed when the storage duration was 15 or 30 days. Previous studies demonstrated that the growth of storage fungi is inhibited at $a_{w} \leq 0.75 \%$ and completely stopped at $\mathrm{a}_{\mathrm{w}} \leq 62 \%$ (Jyoti and Malik, 2013). The longest equilibrium occurred at $\mathrm{a}_{\mathrm{w}}=0.97$ after 20 days of storage. The kernels minimum weight occurred at $\mathrm{a}_{\mathrm{w}}=0.75$ (202.4 g) and the maximum weight gain occurred at $\mathrm{a}_{\mathrm{w}}=0.97$ (210.6 g). Fungal population on storage kernels was affected significantly $(p<0.05)$ by $\mathrm{a}_{\mathrm{w}}$ and equilibrium kernel moisture content in the sorption containers. The relationship between $\mathrm{a}_{\mathrm{w}}$ and equilibrium kernels moisture content during storage was shown in (Figure 1).

\section{Fungal Population}

We isolated 13 fungal species and one unidentified filamentous fungus (isolate A) from kernels at various water activities over the course of 30 days of storage.

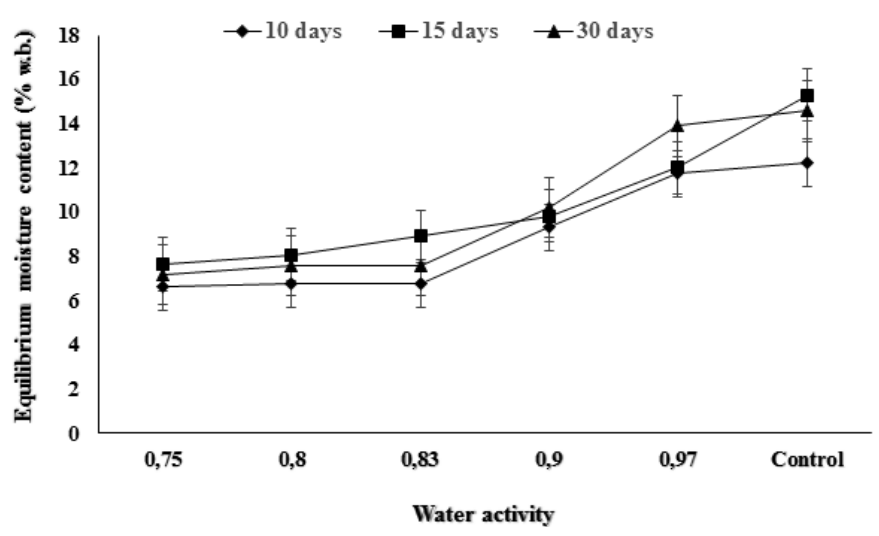

Figure 1. Moisture content of nutmeg kernels after different duration of storage for various water activities at $29^{\circ} \mathrm{C},\left(\right.$ control, $\left.\mathrm{a}_{\mathrm{w}=} 0.99\right)$
These species included Aspergillus candidus, A. flavus, A. niger, A. tamarii, A. wentii, Eurotium chevalieri, Fusarium semitectum, $F$. verticillioides, Penicillium citrinum, $P$. islandicum, Penicillium sp., Cladosporium cladosporioides, Syncephalastrum racemosum, and isolate A.

Water activity, kernel moisture, and storage duration determined fungal growth on nutmeg kernel. The significantly difference of $\mathrm{a}_{\mathrm{w}}$ 0.75-0.83 and $0.90(p<0.05)$ affect total fungal populations. Cladosporium and Fusarium were most prevalent at the beginning of storage. Aspergillus spp. grew after several days of storage. Elshafie et al. (2002) reported that fungal infection occurred either in the field or while the ripe nutmegs were in contact with the soil during harvesting. The presence of fungi at the beginning of the storage revealed that the fungal infection might have occurred during preharvest and harvesting. The process of infection continue while the water activity and kernel moisture maintained fungal growth.

The effect of water activity and storage duration on total fungal population by can be seen in the data presented in Table 1. Each fungal species grow on certain $\mathrm{a}_{\mathrm{w}}$ range. During storage, increasing of $\mathrm{a}_{\mathrm{w}}$ and moisture content followed by the increased of fungal population. However, at $\mathrm{a}_{\mathrm{w}}=0.75,0.80$, and 0.83 low fungal populations were found. The population increased significantly $(p<0.05)$ for kernels stored at $\mathrm{a}_{\mathrm{w}} \geq$ 0.90. Cladosporium cladosporioides was the predominant species during the first period of storage. A relatively small population of this species $\left(0.2 \times 10 \mathrm{CFUg}^{-1}\right)$ was present at $\mathrm{a}_{\mathrm{w}}=0.75$; the population then grow abundantly at $\mathrm{a}_{\mathrm{w}}=$ $0.97\left(1.7 \times 10^{5} \mathrm{CFU} \mathrm{g}^{-1}\right)$. However, the population decreased after 30 days of storage and was replaced by Penicillium, Aspergillus and Eurotium. Bensch et al. (2010) observed that conidia of $C$. cladosporioides were aerial and phyllosphere. We assumed that the fungal infection occurred before fell to the ground. Similar to C. cladosporioides, other species such as Fusarium verticillioides and F. semitectum were found during in the first period of storage at $\mathrm{a}_{\mathrm{w}} \quad 0.80$ and 0.97 .

Among storage fungi, P. citrinum was considered as the most common fungal infection during storage. The species was found in all $\mathrm{a}_{\mathrm{w}}$ levels. At the beginning of storage population of $P$. citrinum was the highest $\left(2.6 \times 10^{5} \mathrm{CFU} \mathrm{g}^{-1}\right)$. Toma and Abdulla (2013), El-Gali (2014) reported that Penicillium spp. and Aspergillus spp. are the most predominant fungi that associated with spices. Conidia of Penicillium spp. and Aspergillus spp. are easily grow in all kinds of substrates and dispersed in the air, therefore they grow abundantly in environment (Bennet, 2010; Krijgsheld et al., 2012).

Eurotium chevalieri was the third most frequent found throughout storage duration. Its population increased with the increased of storage duration. Although E. chevalieri was able to grow at low and wide range $\mathrm{a}_{\mathrm{w}}$, its highest population 


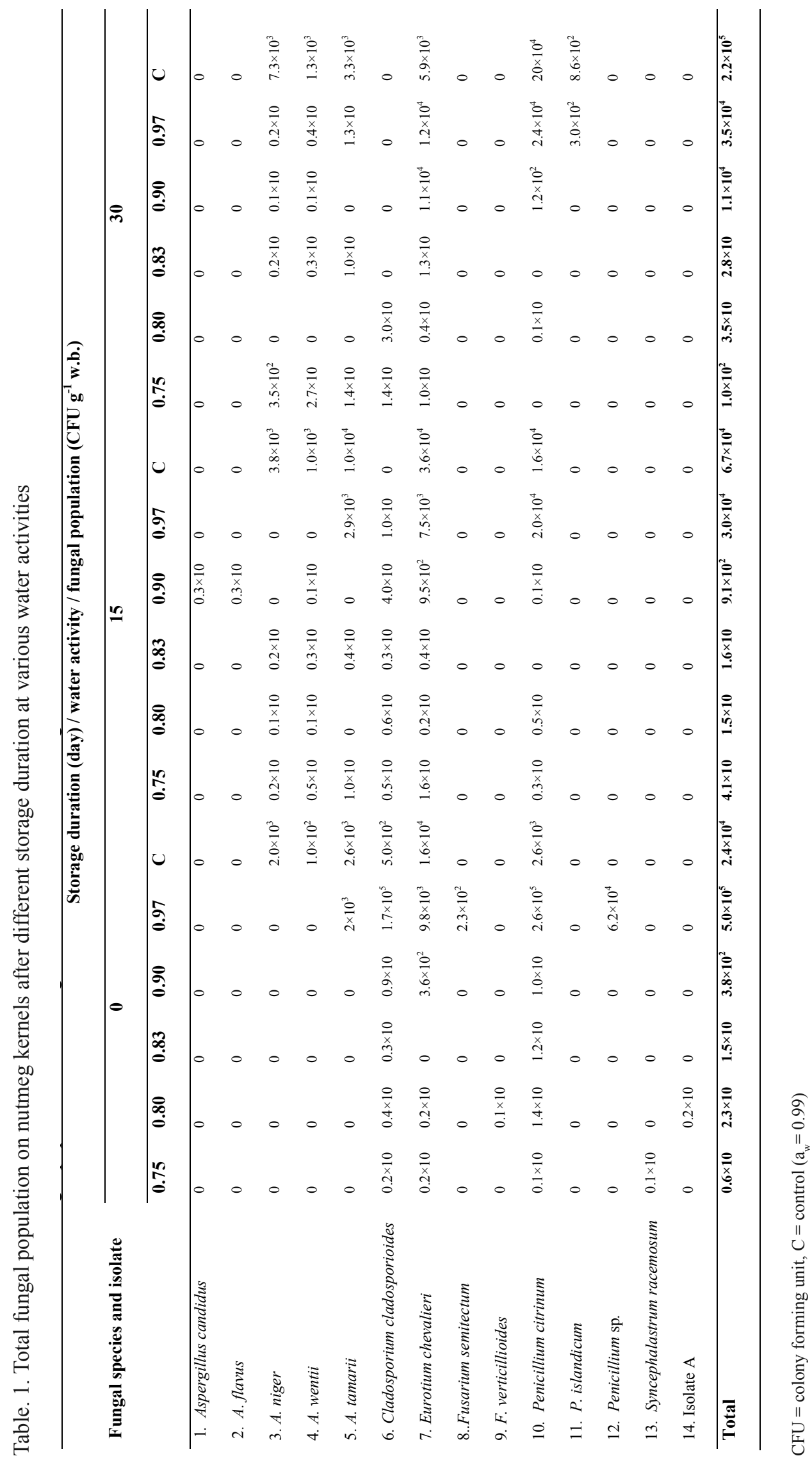


occurred at $\mathrm{a}_{\mathrm{w}}=0.97$. Syncephalastrum racemosum was found at the beginning of storage at $\mathrm{a}_{\mathrm{w}}=0.75$. Its population was $0.1 \times 10 \mathrm{CFU} \mathrm{g}^{-1}$. Pitt and Hocking (2009) reported that $S$. racemosum was tolerant species that able grow at low $\mathrm{a}_{\mathrm{w}}$. The ability of $S$. racemosum to grow in glucose medium at minimum $\mathrm{a}_{\mathrm{w}}=0.84$ was reported by Hocking and Miscamble (1995). The presence of the species was the same $\mathrm{a}_{\mathrm{w}}$ with that of C. cladosporioides, E. chevalieri, and P. citrinum. It was approved that $S$. racemosum was xerophilic and able to grow at low $\mathrm{a}_{\mathrm{w}}(\leq 0.85)$. Five species of Aspergillus were isolated from the kernels after 15 and 30 days of storage. As xerophilic fungi, most species of the Aspergillus found at $\mathrm{a}_{\mathrm{w}} \leq 0.85$ The ability of xerophilic fungi to prevent water loss from their cell due to accumulation of polyol such as glycerol, arabitol, erythritol and mannitol was reported by George et al. (2004). Previous study showed that minimum $\mathrm{a}_{\mathrm{w}}$ for $A$. candidus was at 0.75 (Pitt and Hocking, 2009). Gibson et al. (1994) reported the minimum $\mathrm{a}_{\mathrm{w}}$ for A. flavus was at 0.81 . Among Aspergillus isolated at 30 days of storage at $\mathrm{a}_{\mathrm{w}}=0.75, \mathrm{~A}$. niger was the highest population $\left(3.5 \times 10^{2} \mathrm{CFU} \mathrm{g}^{-1}\right)$. Relationship between seed moisture content during storage, $\mathrm{a}_{\mathrm{w}}$ and fungal growth was presented on Figures 2, 3, and 4.

Cladosporoium cladosporioides was one of the species that was able to grow in wide $\mathrm{a}_{\mathrm{w}}$ range. The species was found particularly in high seed moisture content. and present in each storage duration (Figure 2). The other species such as $F$. verticillioides and $F$. semitectum were found at $\mathrm{a}_{\mathrm{w}}=0.80$ and 0.97. As a field fungi, genus Fusarium were found only at the beginning of storage while seed moisture content still high. However, the fungus becoming inactive or probably dormant after 15 days of storage. The other species such as Eurotium chevalieri and P. citrinum were found at $\mathrm{a}_{\mathrm{w}}=0.75-0.97$. At the beginning of storage Aspergillus niger, A. tamarii and wentii were found only in control $\left(\mathrm{a}_{\mathrm{w}}=0.99\right)$, however, after 15 days (Figure 3 ) and 30 days (Figure 4), these species found at low moisture content and able to grow at $\mathrm{a}_{\mathrm{w}}$ range from 0.75 to 0.97 .

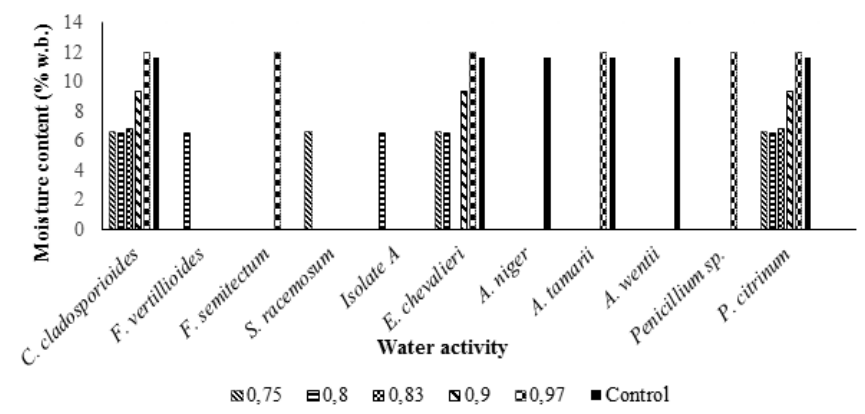

Figure 2. Interaction between water activity, moisture content and fungal population of nutmeg kernels at the beginning of storage

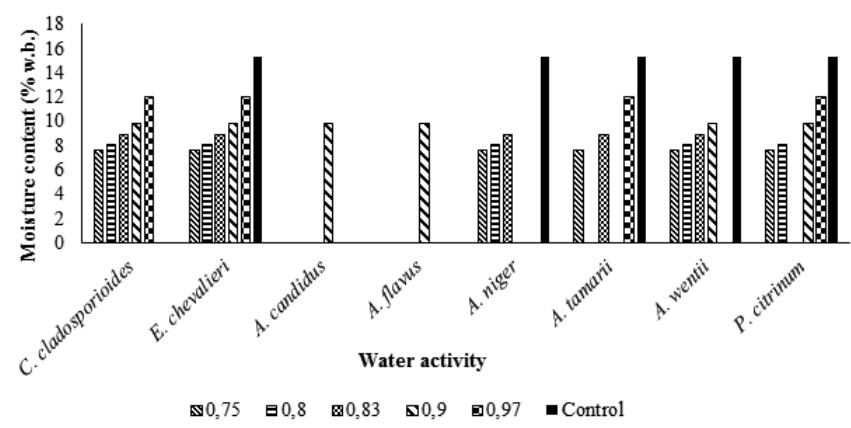

Figure 3. Interaction between water activity, moisture content and tungal population of nutmeg kernels after 15 days of storage

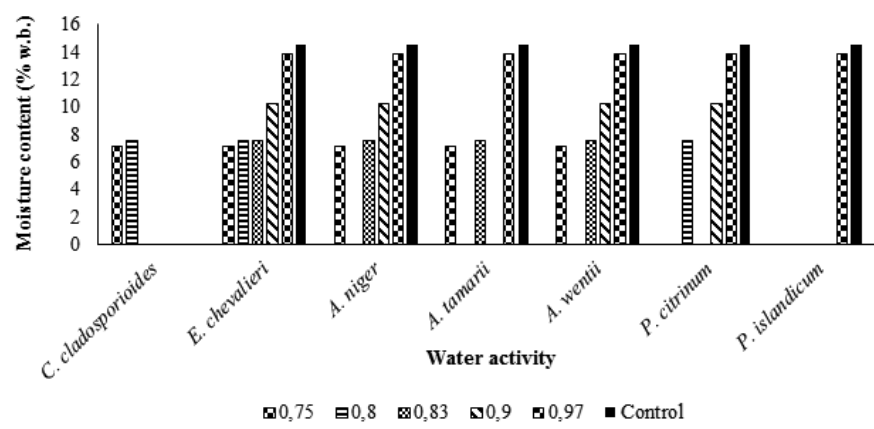

Figure 4. Interaction between water activity, moisture content and fungal population of nutmeg kernels after 30 days of storage

Each fungal species grows on its required $\mathrm{a}_{\mathrm{w}}$. Previous studies reported that critical tolerable minimum of most fungi and yeast at $\mathrm{a}_{\mathrm{w}}=0.62$ (Sjarief,1983). Pitt (1975) observed that several species Aspergillus, Eurotium, and Penicillium were xerophilic and were able to grow at minimum $\mathrm{a}_{\mathrm{w}}$ such as A. candidus (0.75), A. flavus (0.78), A. niger (0.77), A. wentii (0.84), E. chevalieri (0.71), P. citrinum (0.80), and $P$. islandicum (0.83). Aihara et al. (2002) reported that growth inhibition were occurred on Cladosporium. sphaerospermum and $C$. cladosporioides at minimum $\mathrm{a}_{\mathrm{w}}$ requirement. This results is consistent with finding of Pratiwi et al. (2015) who stated that the smallest diameter colony and cell mass of $A$. flavus BIO 2237 was found while the fungus grow at low $\mathrm{a}_{\mathrm{w}}$.

It was assumed that the propagules of $C$. cladosporioides, $F$. semitectum, F. verticillioides, P. citrinum, E. chevalieri, and Aspergillus spp. were in contact on seed while the seeds were still in the field and resist on the seeds during drying and storage. Therefore, seed deterioration caused by fungal infection cannot be prevented (Balesevic-Tubic et al., 2005). Controlling $\mathrm{a}_{\mathrm{w}}$ during storage might prevent fungi to grow (Azis et al., 1998). Postharvest handling methods particularly drying and storing at $\mathrm{a}_{\mathrm{w}}=0.75-0.83$, and maintaining low moisture content of the nutmeg during storage were able to prevent the growth of spoilage fungi. 


\section{CONCLUSION}

Nutmeg kernels harvested by picking from the ground were infected by field and storage fungi. Cladosporium cladosporioides, $P$. citrinum, and E. chevalieri were the most frequent fungi found and present at a wide range of $\mathrm{a}_{\mathrm{w}}$ during storage. Total fungal population increased with the increase $\mathrm{a}_{\mathrm{w}}$ and kernel moisture. Controlling proper condition by maintaining low $\mathrm{a}_{\mathrm{w}}$ during storage is required to minimize fungal population.

\section{ACKNOWLEDGEMENTS}

The results reported herein were made possible by a grant from Directorate General Higher Education, Ministry of Research and Technology Republic of Indonesia Grant No. 017/SP2H/LT/DRPM/II/2016. Southeast Asian Regional Centre for Tropical Biology (SEAMEO BIOTROP) Bogor, Indonesia for research facilities. We may thanks also to Ina Retnowati for technical assistance.

\section{REFERENCES}

Aihara, M., Tanaka, T., Ohta, T. and Takatori, K. (2002). Effect of temperature and water activity on the growth of Cladosporium sphaerospermum and Cladosporium cladosporioides. Biocontrol Science 7(3): 193-196.

Aziz, N.H., Youssef, Y.A., El-Fouly, M.Z. and L.A. Moussa. (1998). Contamination of some common medicinal plant samples and spices by fungi and their mycotoxin. Botanical Bulletin Acad Sinica 39(4): 279-285.

Balesevic-Tubic. S., Malenèiæ, D., Tatiæ M. and Miladinovic, J. (2005). Influencing of aging process on biochemical changes in sunflower seed. Helia 28(42): 107-114.

Bennett, J.W. (2010). Aspergillus Molecular Biology and Genomics, edited by Masayuki Machida and Katsuya Gomi. Caister Academic Press, United Kingdom.

Bensch, K., Groenewald, J.Z., Dijksterhuis, J., StarinkWillemse, M., Andersen, B., Summerell, B.A., Shin, H.D., Dugan, F.M., Schroers, H.J., Braun, U. and Crous, P.W. (2010). Species and ecological diversity within the Cladosporium cladosporioides complex (Davidiellaceae, Capnodiales). Studies in Mycology 67: $1-94$.

Campbell, B.C., Molyneux, R.J. and Schatzki, T.F. (2013). Current research on reducing pre- and postharvest aflatoxin contamination of US almond, pistachio and walnut. Journal of Toxicology 22: 225-266.
Chiou, R.Y.Y., Koehler, P.E. and Beuchat, L.R. (1984). Hygroscopic characteristics of peanut components and their influence on growth and aflatoxin production by Aspergillus parasiticus. Journal of Food Protection 47: 791-794.

Codex Alimentarius Commission (2014). Joint FAO/WHO Food Standards Programme Codex Committee on Spices and Culinary Herbs, First Session. Koichi, India 11-14 February 2014.

Daniel, I.O., Oyekale, K.O., Ajala, M.O., Sanni, L.O., Okelana, M.A., Adetumbi, J.A., Akintobi, D.A.C. and Adebisi, M.A. (2012). Moisture sorption in commercial hybrid maize (Zea mays L.) seeds during storage at ambient tropical conditions. Research Journal of Seed Science 5(1): 32-37.

Dharmaputra, O.S., Ambarwati, S., Retnowati, I. and Nurfadila, N. (2015). Fungal infection and aflatoxin contamination in stored nutmeg (Myristica frargrans) kernels at various stages of delivery chain in North Sulawesi Province. Biotropia 22(2): 129-139.

Directorate General of Estate Crops (2013). Tree Corp Estate Statistics of Indonesia 2012-2014. Spices and Beverage Crops. Ministry of Agriculture. Jakarta, Indonesia.

El-Gali (2014). Spices in original form. Global Journal of Scientific Researches 2(3): 83-88.

Elshafie, A E., Al-Rashdi, T.A., Al-Bahri, S.N. and Bakheit, C.S. (2002). Fungi and aflatoxins associated with spices in the Sultanate of Oman. Mycopathologia 155(3): $155-160$.

George, J., Ruijter, G., Visser, J. and Rinzema, A. (2004). Polyol accumulation by Aspergillus oryzae at low water activity in solid-state fermentation. Microbiology 150: 1095-1101.

Gibson, A.M., Baranyi, J., Pitt, J.I., Eyles, M.J. and Roberts, T.A. (1994). Predicting fungal growth: the effect of water activity on Aspergillus flavus and related species. International Journal of Food Microbiology 23: 419431.

Hocking, A.D. and Miscamble, B.F. (1995). Water relations of some Zygomycetes isolated from food. Mycological Research 99(9): 1113-1118.

Hussain, A., Sohail, M. and Shafqatullah (2012). Aflatoxin contamination of spices sold in different markets of Peshawar. Journal Chemical Society of Pakistan 34(5): 1052-1055. 
Jayas, D.S. and White, N.D.G. (2003). Storage and drying of grain in Canada: low cost approaches. Food Control 14(4): 255-261.

Jyoti and Malik, C.P. (2013). Seed deterioration: A review. International Journal of Life Sciences Biotechnology and Pharma Research 2(3): 374-385.

Kitic, D., Denise, C., Jardim, P., Favetto, G.J., Resnik, S.L. and Chirife, J. (1986). Theoretical prediction of the water activity of standard saturated solutions at various temperatures. Journal of Food Science 51(4): 10371041.

Kneifel, Wolfgang, Berger and Erika (1994). Microbial criteria of random samples of spices and herbs retailed on the Austrian market. Journal of Food Protection 10: 854-941.

Krijgsheld, P., Bleichrodt, R., van Veluw, G.J., Wang, F., Müller, W.H., Dijksterhuis and J. Wösten, H.A.B. (2012). Development in Aspergillus. Studies in Mycology 74: 1-29.

Martins, M.L., Martins, H.M. and Bernardo, F. (2001). Aflatoxins in spices marketed in Portugal. Food Additives and Contaminants 18: 315-319.

Pitt, J.I. (1975). Xerophilic fungi and the spoilage of foods of plant organisms. In: Duckworth, R.B. Water Relations of Foods, p. 273-307. Academic Press, London.

Pitt, J.I. and Hocking, A.D. (2009). Fungi and Food Spoilage. $3^{\text {rd }}$ edn. Springer, New York.
Pratiwi, C., Rahayu, W.P., Lioe, H.H., Herawati, D., Broto, D. and Ambarwati, S. (2015). The effect of temperature and relative humidity for Aspergillus flavus $\mathrm{BIO}$ 2237 growth and aflatoxin production on soybeans. International Food Research Journal 22(1): 82-87.

Syarief, R. (1983). Influence des conditions hydrothermiques de stokage sur les qualites microbiologiques et technologiques du grain. $\mathrm{PhD}$ dissertation, Universite de Nantes, French.

Škrinjar, M.M., Janković, V.V., Vesković, S.M., Moračanin and Vukojević, J.B. (2012). Xerophilic moulds isolated from spices used in meat industry as potential producers of mycotoxins. Proceedings National Science Matica Srpska Novi Sad 123: 7-16.

Standar Nasional Indonesia (SNI) 01-0006 (1993). Biji Pala. Badan Standardisasi Nasional.

Stankovic, N., Komic, L. and Kocic, B. (2006). Microbiological correctness of spices on sale in health food stores and supermarket in Nis. Acta Fac Med Naiss 23(2): 79-84.

Toma, F.M. and Abdulla, N.Q.F. (2013). Isolation and identification of fungi from spices and medicinal plants. Research Journal of Environmental and Earth Sciences 5(3): 131-138.

Varga, J., Frisvad, J.C. and Samson, R.A. (2009). A reappraisal of fungi producing aflatoxins. World Mycotoxin Journal 2(3): 263-277. 